\title{
KÜNT TORAKS TRAVMASI
}

\author{
BLUNT THORACIC TRAUMA
}

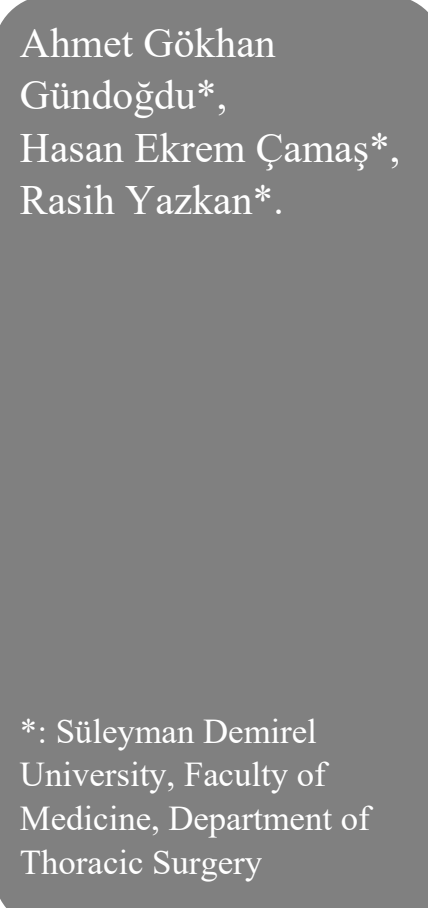

Yazışma Adresi:

Ahmet Gökhan Gündoğdu

Süleyman Demirel

University, Faculty of

Medicine, Department of

Thoracic Surgery

Çünür Mah. 32246 Isparta/

TURKEY

gokhangundogdu@hotmail.

com

$533 / 2506281$
Öz

Travma 40 yaş altında görülen ölümlerin en sık nedenidir. Vakaların hemen hemen dörtte biri toraks travmasıdır ve bunların da önemli bir yüzdesini künt travmalar oluşturur. Yaralanma izgesi minör vakalardan ciddi, hayatı tehdit edenlere kadar çeşitlilik gösterebilir. Künt toraks travması hakkında yeterli bilgi sahibi olunması ve travmanın meydana geldiği yerde başlayan uygun bakım, morbidite ve mortalitenin azaltılmasinda son derece önemlidir.

Anahtar Kelimeler: künt, tor aks, travma

\begin{abstract}
:
Trauma is the most common cause of death under 40 years of age. Almost a quarter of these cases are thoracic trauma, in which blunt ones constitute a major percentage. The spectrum of the injuries may vary from minor ones to severe lifethreatening cases. Adequate knowledge on blunt thoracic trauma and proper care starting at the site of the impact are crucial for decreasing morbidity and mortality rates.
\end{abstract}

Keywords: blunt, thorax, trauma 


\section{BLUNT THORACIC TRAUMA}

Adequate knowledge about thoracic trauma and associated injuries is crucial for proper management of trauma victims. Edwin Smith papyrus reports on thoracic trauma and related surgical issues in $1600 \mathrm{BC}(1)$. In the fifth century BC, Hippocrates defined hemoptysis caused by rib fractures. He stated this to be a serious pathology, referring to pulmonary injury. In 1773, William Bromfield mentioned about tension pneumothorax and he performed thoracentesis. With the advent of closed chest drainage, thoracic injury management was better performed. Playfair used the water seal drainage system for the first time in 1875 (2).

Trauma, although being the third most common over 40 years of age, is the most common cause of death under the age 40 (3). About $25 \%$ of these casualties are due to thoracic trauma. Around $70 \%$ of thoracic trauma are blunt. The associated injuries may range from simple, isolated rib fracture to grave vascular hemorrhage necessitating thoracotomy. Pulmonary contusion is the most commonly encountered intrathoracic pathology in blunt trauma. Severe intrathoracic injuries are more common in multitrauma patients. The mortality rate of the thoracic trauma is 4 to $12 \%$. This rate may rise up to 30 to $35 \%$ when multiple traumas exist (4). The most common accompanying injuries are fractures of the extremities, head trauma, abdominal injury, pelvic fractures and spinal injuries with decreasing order of frequency. In about $50 \%$ of the motor vehicle accidents resulting in death, severe thoracic trauma is present $(5,6)$.

\section{Rib Fracture:}

Rib fractures are the most common injury observed with blunt thoracic trauma. Usually 4th to 9th ribs are affected. The involvement of the first 2 ribs suggests a high energy trauma and damage to the subclavian vessels and brachial plexus may accompany the situation. In cases of lower rib fractures, possible injury to the abdominal organs must be carefully sought. Hepatic and splenic injuries may be observed with the fracture of 11th and 12th ribs. In cases of rib fractures immediate pain relief and pulmonary rehabilitation is crucial. For pain management; oral and parenteral nonsteroidal anti-inflammatory drugs, narcotics, intercostal nerve blockade and epidural analgesia may be used (2).

\section{Pulmonary Parechymal Laceration:}

Pulmonary parenchymal laceration may be observed with blunt thoracic trauma, altough it is more common with penetrating chest wounds. It may be the result of rib fractures or deceleration type trauma. It is usually accompanied by hemoptysis and hemothorax. Both the vascular structure and airway injuries occur. In most cases the main problem is pneumothorax. If the visceral pleura remains intact, blood and air may be trapped within the parenchyme giving rise to hematoma, cyst or blood filled cystic lesion (7).

\section{Pulmonary Hematoma:}

The incidence of developing pulmonary hematoma is 4 to $10 \%$ in pulmonary contusion cases. It may be difficult to differentiate pulmonary hematoma from pulmonary contusion because of the surrounding intraparenchymal hemorrhage. Typically, a well-demarcated nodular formation of 2 to 5 $\mathrm{cm}$ in size develops within 24 to 48 hours after the trauma. Computed tomography of the chest may help in detection. It is usually 
asymptomatic, but may cause moderate pain and hemoptysis. Most often the pathologic situation does not interfere with gas exchange and spontaneous resorption takes place within 2 to 6 weeks. Rarely, secondary infection and abcess formation, which needs to be drained, may develop. Fever and dyspnea may be observed then. Usually, immediate chest X-ray following the trauma yields no sign of hematoma (7).

\section{Traumatic Pulmonary Pseudocyst:}

Thoracic trauma, although rare, may give rise to a well-demarcated, air, liquid or blood filled cystic cavity lacking an epithelial lining. This usually takes place after blunt trauma. It is rare compared to intrapulmonary hematoma or pulmonary contusion (8). Two mechanisms have been proposed for the development of pulmonary pseudocysts in high energy motor vehicle accidents related to the exposure of the lungs to immense forces. First one is the closure of a segment of the bronchial tree due to sudden compression of a certain area of the lung. The closed segment later on enlarges as a result of the alveolar rupture. Second probable mechanism is the production of contusion waves tearing the pulmonary parenchyma (9). Children and young adults are more prone to such injuries because of the hyperflexibility of the chest wall facillitating the visceral pleura to stay intact in spite of the massive forces applied on the pulmonary parenchyma. For this specific reason $85 \%$ of the traumatic pulmonary pseudocyst patients are less than 30 years of age (10). The pseudocysts may be solitary or multiple, oval or spheric and the size ranges from 2 to $14 \mathrm{~cm}$ (11).

\section{Costal Cartilage Damage:}

Especially children suffer such phenomenon when a trauma exerts from the anterior. The ribs detach from costal cartilages or the sternum. The usual symptom is pain and the situation resolves spontaneously in few weeks.

\section{Hemothorax:}

Hemothorax develops as a result of damage to the intercostal artery, lung, diaphragm, heart, pericardium, aorta and its branches. Occasionally, intraabdominal bleeding may leak through the diaphragmatic musculature into the thoracic cavity. For diagnosis on the basis of chest X-ray, the position of the patient is extremely important. Lateral decubitus position or standing upright are favored (2).

\section{Pneumothorax:}

Pneumothorax briefly can be described as the entry of air inside the pleural cavity, which causes pulmonary collapse of varying amounts. Normally, the pleural cavity contains little fluid amounting to 5 to $10 \mathrm{ml}$. Presence of air is abnormal. Pneumothorax develops as a result of disrupted continuity of either the visceral or parietal pleura. This may be caused by a blunt or penetrating trauma or the tear of the lung parenchyma along with the visceral pleura which wraps it thoroughly. In case of any attachment between the plevral layers, localized pneumothorax may be observed. If there is free entry of air inside the pleural cavity during respiration, the situation is called open pneumothorax. If the air entering the pleural cavity during inspiration fails to leave the cavity during expiration and goes on accumulating, it gives rise to tension 
pneumothorax. Fluid may accompany air inside the pleural cavity, which is called hydropneumothorax. Blunt or penetrating thoracic trauma, chronic interstitial pulmonary diseases, metastatic pulmonary disease and iatrogenic reasons may give rise to pneumothorax. However, most common reason is spontaneous pneumothorax, which is usually observed in young, thin, tall and otherwise healthy individuals. This is generally caused by rupture of the small, subpleural, congenital blebs. These blebs may be bilateral in location. Spontaneous pneumothorax is observed 8 times more in men compared to women. Spontaneous pneumothorax is recurrent with a possibility of 30 to $70 \%$ on the affected side. The contralateral side may ve affected $10 \%$ of the cases after the initial episode. The patients usually complain of sudden onset chest pain and dyspnea. Cyanosis may be observed in tension pneumothorax (12).

\section{Subcutaneous Emphysema:}

Subcutaneous emphysema is simply the presence of air beneath the skin. Main causes are tears in the skin allowing entry of air, tear of the parietal pleura in case of pneumothorax, migration of the air from mediastinal emphysema and passage of air from pleural cavity to the subcutaneous tissues in localized pneumothorax cases in which pleural adhesions exist. Occasionally, air is trapped in mediastinum, neck and face after trauma. This air sometimes migrates all along the subcutaneous tissues throughout the body. Accumulation of excess air in between the aponeuroses may compress the vena cavae. Mediastinotomy is helpful in such cases (13).

\section{Pneumomediastinum:}

Pneumomediastinum is defined as the presence of air inside the mediastinum. Alveolar rupture leads to pneumomediastinum in blunt thoracic trauma. It may be observed following blunt thoracic trauma, tracheostomy, endoscopy, bronchoscopy and mechanical ventilation due to barotrauma. The treatment is usually conservative.

\section{Sternal Fracture:}

Sternal fractures are quite frequent. Usually, the fracture axis is transverse. The fracture is generally detected with inspection and palpation. Lateral chest X-ray confirms the diagnosis. Sternum gets fractured either by direct trauma or by hyperflexion indirectly. In about $55 \%$ cases severe intrathoracic injury is present. It causes excessive pain when there is displacement. Reduction may be performed by traction or surgically. Respiratory physiotherapy and analgesics are important for treatment. Pseudoarthrosis is rare (13).

\section{Flail Chest:}

Flail chest is segmental unstabilization of the chest wall. It is observed when at least three consecutive ribs get fractured from at least 2 different points. Its incidence may be as high as $5 \%$ in thoracic trauma according to LoCicero (14). Segmental paradoxical movement of the thoracic cage is observed. This paradoxical movement decreases the vital capacity rendering the ventilation to be ineffective. The accompanying pulmonary contusion may also contribute to respiratory insufficiency (15). If the flail segment is in a small, restricted area; proper analgesia, pulmonary toilet, oxygen 
administration may be sufficient for management. The general status of the patient might be misleading thus arterial blood gas analysis must be performed for follow-up. Paradoxical movement itself is not an absolute indication for mechanical ventilation (16). Mechanical ventilatory support may be as long as 3 weeks, as the fibrous stabilization of the thoracic cage takes place (17). The rate of flail chest varies as depicted in different series. It is $8 \%$ as stated by Galan et al (18), and $1.5 \%$ as suggested by Çağırıcı et al (19). In patients who need mechanical ventilation positive end expiratory pressure helps in stabilization of the thoracic cage $(20,21)$. The mortality is closely dependent on the presence of pulmonary contusion, massive hemothorax and the development of acute respiratory distress syndrome (22). The mortality rate varies from 11 to $22 \%$ (23).

\section{Diaphragmatic Injury:}

In case of penetrating injuries small tears may develop on the diaphragm, whereas blunt trauma may lead to large radial tears. Blunt trauma may cause rupture especially on the posterior part of the diaphragm where it is congenitally weak. The mechanism of the trauma is the increased pressure. Intra-abdominal pressure rise is transmitted. Motor vehicle accidents and falls from certain high levels in which there is huge energy, the diaphragm may be injured severely. And the defects in respiratory mechanics may facillitate early diagnosis $(24,25)$. Since the liver itself kind of guards the right hemidiaphragm, left side is more commonly affected. But when there is rupture on the right side, since the impact is considered to be bigger, mortality rates are higher. Diaphragmatic rupture also usually points out to an accompanying intra-abdominal injury. The diagnostic capability of plain chest X-ray is reported to be 27 to $62 \%$ on the left and $17 \%$ on the right side $(26,27)$. In patients with mechanical ventilatory support, the positive end expiratory pressure may hinder intra-abdominal organ herniation inside the thoracic cavity. Thus, only the post-extubation X-ray may reveal hernia. Computed tomography and magnetic resonance imaging may be useful in diagnosis. However, direct visualization during laparoscopy, laparotomy, thoracoscopy or thoracotomy is the gold standard in diagnosis. Surgical repair is necessary for management. In acute cases laparotomy is easier, whereas in chronic cases thoracotomy is favored. Although many variations may exist, the safest fashion of repair seems to be using nonabsorbable interrupted mattress sutures.

\section{Traumatic Asphyxia:}

Traumatic asphyxia is caused by forceful blunt trauma of the thorax. Petechial hemorrhages are observed on the face and upper parts of the thorax. Subconjunctival hemorrhage, cervical cyanosis and less commonly neurologic problems may accompany (28). Retinal edema may give rise to temporary loss of vision. High energy trauma exerted on the thoracic cage of a person during deep inspiration when the glottis is open causes asphyxia. Supportive care is sufficient whenever there is no accompanying injury of other systems $(29,30)$.

\section{Tracheobronchial Injury:}

Tracheobronchial injuries are more commonly 
seen following motor vehicle accidents. Around $30 \%$ of such injuries are fatal. More than $80 \%$ occur in $2.5 \mathrm{~cm}$ distance within the carina (31). Since the cervical trachea is well protected by the surrounding bony structures, the intrathoracic part of the trachea and the bronchi are more commonly injured. Since the close relationship of the trachea with the vital intrathoracic organs, accompanying injuries are of primary importance. When extrapleural rupture occurs pneumomediastinum and subcuatenous emphysema are observed. Intrapleural rupture favors an incremental respiratory distress. Upon chest tube insertion, massive air leak is observed and the lung fails to expand. In about $90 \%$ patients, chest X-ray reveals a pathology such as pneumothorax, pleural effusion, subcutaneous emphysema, ipsilateral rib fracture and mediastinal hematoma. The specific radiological signs for tracheobronchial injuries are peribronchial air, deep cervical emphysema seen as a radiolucent line along the prevertebral fascia, mediastinal emphysema and fallen lung sign. Patients should be started inhaling 100\% oxygen. Bronchoscopy must be carried out immediately if the general status of the patient is stable. The endotracheal tube shall be pushed to the unaffected side if the injury is at bronchial level. This fascillitates ventilation and also prevents entry of the hemorrhagic secretions to the unaffected side. The treatment for complete transection is anastomosis of the injured segment (32). However, detailed repair technics are beyond the scope of this paper.

\section{Blunt Cardiac Injury:}

Cardiac contusion may the most commonly missed pathology following trauma. It occurs as a result of direct compression of the heart or deceleration traumas. Cardiac contusion is encountered most often with sternal fractures and the right ventricle is affected in majority of the cases. The diagnosis is made with history of the trauma to explain the possible mechanism, cardiac enzyme tests, ECG evaluation and echocardiography. Some rhythm disorders such as sinus tachycardia, supraventricular tachycardia and ventricular extrasystoles may be observed in about $20 \%$ patients with cardiac contusion. In rare cases, branch blocks and complete blocks may occur, but usually the need for pacemaker is rare. Myocardial contusion leads to low cardiac output as a result of such reasons as decreased cardiac contractility, decreased ventricular compliance and cardiac insufficiency. Nonspecific ST-T changes may be observed on ECG. Troponin I and troponin $\mathrm{T}$ levels are sensitive for evaluation of the cardiac status (33).

\section{Cardiac Tamponade:}

Cardiac tamponade is more frequent in penetrating injuries. Accumulation of as little as 150 to $200 \mathrm{cc}$ hemorrhagic fluid within the pericardial cavity may lead to tamponade (34). Pericardial tamponade must be questioned in patients with acidosis, base deficit and hypotension despite the adequate volume replacement. Beck's triad (jugular venous distention, hypotension, distant heart sounds) is present in only about one third of the patients (35). Pulsus paradoxus and Kussmaul's sign may be observed. The difference between the systolic and diastolic blood pressures may decrease along with hypotension. Central 
venous pressure increases. Mediastinum is enlarged on chest X-ray. Low amplitude QRS complexes appear on ECG. The diagnosis is confirmed by detection of pericardial fluid inside the pericardial layers.

\section{Esophageal Injury:}

Esophageal injury is rare. It is usually seen in penetrating traumas. If the diagnosis is missed, the patients may develop mediastinitis which is extremely mortal. Patients generally complain about a pain which commences on epigastrium and migrates to the chest. Rapid onset dyspnea, cyanosis and shock may develop. Detection of localized hematoma or laceration on esophagoscopy confirms the diagnosis. The treatment is surgical repair and drainage of the mediastinal and pleural cavities. Broad spectrum antibiotics must be administered (36). Survival is reported to be $87 \%$ in patients which undergo surgery within the first 24 hours of the esophageal perforation. This rate decreases to $55 \%$ when the surgery is delayed (37).

\section{Pulmonary Contusion:}

The energy of the trauma once absorbed by the thoracic cage is transmitted to the lungs. This energy causes alveolar distention, alveolar rupture, detachment of the alveoli from the bronchioles, intra-alveolar bleeding and interstitial edema. This overall pathology is referred as pulmonary contusion. Pulmonary contusion occurs in about 30 to $77 \%$ of the major thoracic trauma cases. It is more frequent in areas adjacent to the thoracic cage, diaphragm and mediastinum. The extent of the contusion is dependent on the severity of the trauma and the amount of alveolocapillary damage. Pulmonary contusion may be solitary in children, whereas accompanying injuries are present in adults (7). Mechanisms for the development of pulmonary contusion have been defined as: distention and laceration of the alveoli as a result of the positive pressure from the impact, detachment of the alveoli and bronchi as the impact causes them to move at different velocity, disruption of the bronchioloalveolar common surface because of the high energy wave (38). Shortly after the trauma, edema develops around a central hemorrhagic area. Inflammatory cells migrate around the alveoli. Since the alveoli fail to function properly, oxygenation at these injured sites get impaired. Partial oxygen pressure may fall in the first 24 hours. Moreover, there is an increase in the amount of secretion in the unaffected alveoli and the bronchial tree fill up with hemorrhagic fluid. This eventually leads to atelectasis and consolidation. This aggravates the clinical status of the patient. Lung compliance decreases as a result of the fall in surfactant content. Pulmonary vascular resistance rises. Microcirculatory shock ensues leading to the development of oxygen free radicals (39). Both the systemic and pulmonary capillary permeability increase causing edema. Blunt thoracic trauma, either accompained by a head trauma or not, causes systemic neural discharge. This futher increases the peripheric vascular resistance and the cardiac response as an answer.

The first step after securing the airway should be the evaluation of effective and sufficient breathing. Respiratory rate, dyspnea, cyanosis, control of the secretions must be evaluated. Unless otherwise proven, every thoracic trauma 
patient shall be suspected of pulmonary contusion (40). Usually dyspnea, tachycardia, hemoptysis, cyanosis, tachypnea and hypotension are observed. Non-productive cough may develop few hours after the trauma. Chest X-ray which is obtained right after the trauma may not reveal any pathology. The radiological changes may take 6 to 24 hours to develop. Patchy type opacity increase may be seen on chest X-ray. Such lesions may be solitary or multiple. Detection of such finding on the immediate X-ray is diagnostic as acute respiratory distress syndrome and pneumonia usually develop later. Computed tomography of the chest is highly sensitive in diagnosis (41, 42). The contusion generally starts to resolve in 4 to 6 days in uncomplicated cases.

Pulmonary contusion patients must be followed closely. The clinical situation may aggravate quite rapidly. The mainstay of treatment is the respiratory support. Oxygen supply must be enough to keep the partial oxygen pressure above $60 \mathrm{mmHg}$. Overhydration of the patient must be avoided (9). Whenever the need arises, pulmonary artery pressure and pulmonary capillary wedge pressure calculations must be carried out. High dose corticosteroid administration of short duration may be done. Adequte pulmonary toilet and pulmonary rehabilitation are of paramount importance for the prevention of atelectasis and clearance of the secretions. The use of antibiotics are still debated. Prophylactic antibiotic use is yet to be proven useful, although some studies suggest it (13)

\section{Acute Lung Injury:}

Acute lung injury (ALI) as defined by
Dupuytren in 19th century is seen in most of blunt thoracic trauma patients (43). The injury may range from ALI to acute respiratory distress syndrome according to the magnitude of the impact. In ALI, intracellular and extracellular edema develop to impair the alveolocapillary permeability which leads to hypoxia. Vital capacity, tidal volume, arterial oxygenation and compliance decrease. Increased pulmonary secretions obstruct the bronchioles leading to atelectasis. ALI gives rise to arteriovenous shunts. ALI may be seen in about $75 \%$ of the flail chest patients (44). Dyspnea, hypoxemia, cyanosis, tachycardia, hemoptysis may be the presenting symptoms. Impaired ventilation/perfusion ratio causes intrapulmonary shunts and decreases compliance of the lungs. Hypoxia and impaired ventilation may become prominent in 24 to 48 hours (45). The onset is usually sudden. The ratio of partial oxygen pressure to fraction of inhaled oxygen is less than or equal to 300 . Diffuse, bilateral infiltration is observed on chest X-ray. Pulmonary capillary wedge pressure is usually less than $18 \mathrm{mmHg}$. The treatment is ususally supportive. If severe hypoxemia fails to develop,usually the cases begin to improve in about 48 to 72 hours. Complete resolution is usually seen in about one week (46, 47). Measures such as nasotracheal aspiration, respiratory physiotherapy, pain control and ventilatory support whenever needed are important to prevent the development of pneumonia. Furosemide acts double fold as it has diuretic role and it also acts on pulmonary vasculature to decrease vascular resistance, lower pulmonary capillary hydrostatic pressure and 
decrease intracellular fluid $(48,49)$.

\section{Acute Respiratory Distress Syndrome:}

Acute respiratory distress syndrome (ARDS) was first described in 1967 by Ashbaugh et al (50). ARDS is characterized by bilateral, diffuse infiltration of lungs of non-cardiogenic nature and it is usually unresponsive to oxygen treatment. Although its incidence may be as low as 3 to 8 per 100000 , the mortality rate may be as high as $90 \%$. ARDS may be primary or secondary in etiology. Primary causes are pneumonia, aspiration, pulmonary contusion, toxic fume inhalation and drowning. Secondary causes are sepsis, trauma, hypovolemic shock, blood transfusion, acute pancreatitis, drug intoxication and longlasting cardiac surgery (51). ARDS is the furthermost end of ALI. In addition to intracellular edema, increased airway pressure and hypoxemia as observed in ALI; cytokine release, stimulation of monocyte -macrophage, complement and coagulationfibrinolysis systems and neutrophil migration take place.

There are 3 stages in the development of ARDS which overlap each other. In the inflammatory stage, edema fluid which is rich in protein leaks into the interstitium and the alveolar spaces. It lasts 1 to 4 days. There is increased permeability of the endothelium and the alveolar epithelium. Alveolar injury, edema and the development of hyalene membranes are seen microscopically. The second stage is proliferative. Proliferation of alveolar type II cells and myofibroblast infiltration are observed. There is also increased pulmonary arterial pressure. Fibrotic stage is the third one. It takes place around 10 to 14 th days.
Destruction of the alveoli, emphysematous changes, fibrosis, chronic pulmonary disease take place (51). In the early stages of ARDS, neutrophils and neutophilic deposits are observed in brochoalveolar lavage fluid (52). Platelets aggravate endothelial damage by means of the mediators they release. The antioxidant levels are decreased in ARDS (53).

Sudden onset dyspnea, hypoxemia, a ratio of partial oxygen pressure to fraction of inhaled oxygen less than 200, bilateral consolidation on chest X-ray, left venticular failure symptoms and a pulmonary capillary wedge pressure of less than $18 \mathrm{mmHg}$ favor ARDS (54).

The aim of treatment is to facilitate adequate gas exchange for tissue oxygenation, stop the reactions giving rise to pulmonary damage and eliminate any underlying causes. It is important to maintain fluid and electrolyte balance. Excess fluid administration must be avoided. Proper antibiotic treatment is needed for accompanying pneumonia. Sufficient pulmonary toilet must be achieved and mechanical ventilatory support must be started whenever needed. Enteral nutrition must be started as early as possible.

In conclusion, trauma is the leading cause of death under 40 years of age. Around $25 \%$ of such trauma are thoracic, and the majority of the thoracic trauma cases are blunt. The initial evaluation and appropriate care of the victim at the site of the injury is crucial, since it is effective on the morbidity and mortality rates. 


\section{References:}

1)Breasted JH. The Edwin Smith Papyrus, 2 vols, Oriental Institute Publications 3-4. Chicago: University of Chicago Press; 1930

2)Graeber G, Prabhakar G, Shields T. Blunt and penetrating injuries of the chest wall, pleura, and lungs. General thoracic surgery 6th ed Philadelphia: Lippincott Williams and Wilkins. 2005:951-71.

3)Ertekin C. Multiple travmalı hastaya yaklaşım. Yoğun Bakım Dergisi. 2002;2:77-87.

4)Çobanoğlu U, Yalçınkaya İ. Toraks yaralanmaları. Ulus Travma Acil Cerrahi Derg. 2010;16(1):77-83.

5)Boyd AD. Chest wall trauma. Thoracic Trauma Philadelphia: WB Saunders Company. 1989:101-32.

6)Sriussadaporn S, Luengtaviboon K, Benjacholamas V, Singhatanadgige S. Significance of a widened mediastinum in blunt chest trauma patients. Journal of the Medical Association of Thailand= Chotmaihet thangphaet. 2000;83(11):1296-301.

7)Altınok T. Akciğer Yaralanmaları. TTD Toraks Cerrahisi Bülteni 2010;1:55-9.

8)Melloni G, Cremona G, Ciriaco P, Pansera M, Carretta A, Negri G, et al. Diagnosis and treatment of traumatic pulmonary pseudocysts. Journal of Trauma and Acute Care Surgery. 2003;54(4):737-43.

9)De A, Peden C, Nolan J. Traumatic pulmonary pseudocysts. Anaesthesia. 2007;62(4):409-11.

10)Athanassiadi K, Gerazounis $M$, Kalantzi N, Kazakidis P, Fakou A, Kourousis D. Primary traumatic pulmonary pseudocysts: a rare entity. European journal of cardiothoracic surgery. 2003;23(1):43-5.

11)Shirakusa $T$, Araki $Y$, Tsutsui $M$, Motonaga R, Iwanaga M, Ogami H, et al. Traumatic lung pseudocyst. Thorax. 1987;42(7):516-9.

12)Turgut AT, Koşar U, Bilaloğlu P. Pnömotoraks ve radyolojik tanis1. Sted. 2001;10:335-7.

13)Tüzün H. Künt Toraks Travmaları: Cerrahpaşa Tıp Fakültesi sürekli tıp eğitimi etkinlikleri kitle yaralanmaları ve afet hekimliği sempozyumu; 2000. 8391.
14)Battistella F, Benfield JR. Blunt and penetrating injuries of the chest wall, pleura and lungs. General thoracic surgery 5th ed Philadelphia: Lippincott Williams \& Wilkins. 2000:815-31.

15)Soysal Ö. Künt göğüs travmaları. Yüksel M, Kalaycı N, editors. İstanbul: Bilmedya Grup; 2001. 447-64.

16)Mansour K, Bongiorno P. Blunt trauma: Chest wall, lung, pleura, heart, great vessels, thoracic duct, and esophagus. Pearson F, Cooper J, Deslauries J, et al. 2002;2:1832-49.

17)Kemmerer WT, Eckert WG, Gathright JB, Reemtsma $\mathrm{K}$, Creech JR O. Patterns of thoracic injuries in fatal traffic accidents. Journal of Trauma and Acute Care Surgery. 1961;1(6):595.

18)Shorr RM, Crittenden M, Indeck M, Hartunian SL, Rodriguez A. Blunt thoracic trauma. Analysis of 515 patients. Annals of surgery. 1987;206(2):200.

19)Çağırıcı U, Uç H, Çalkavur T, Gürcün U, Badak İ, Bilkay Ö, et al. Toraks travmaları: 6 yıllık deneyimlerimiz. Ulus Travma Derg. 1998;4:248-52.

20)Budunelli T. Künt göğüs travmalarında IPPV tedavisi. İzmir Devlet Hastanesi Mecmuası 1976. 67781

21)Haenel J, Moore F, Moore E. Pulmonary consequences of severe chest trauma. Respiratory care clinics of North America. 1996;2(3):401-24.

22)Maslov V, Takhtamysh M, Kretov A. Treatment of multiple ribs fractures. Khirurgiia. 1999(4):32-5.

23)Demuth WJ, Smith J, . Pulmonary contusion. Am J Surg 1965. 819-23.

24)Shah R, Sabanathan S, Mearns AJ, Choudhury AK. Traumatic rupture of diaphragm. The Annals of thoracic surgery. 1995;60(5):1444-9.

25)Lee W, Chen R-J, Fang JF, Wang C, Chen H-Y, Chen $\mathrm{S}-\mathrm{C}$, et al. Rupture of the diaphragm after blunt trauma. The European journal of surgery, Acta chirurgica. 1994;160(9):479-83.

26)Shanmuganathan $K$, Killeen $K$, Mirvis SE, White CS. Imaging of diaphragmatic injuries. Journal of thoracic imaging. 2000;15(2):104-11. 
27)Bergin D, Ennis R, Keogh C, Fenlon HM, Murray JG. The "dependent viscera" sign in CT diagnosis of blunt traumatic diaphragmatic rupture. American Journal of Roentgenology. 2001;177(5):1137-40.

28)Gulbahar G, Kaplan T, Gundogdu AG, Baran HN, Kazanci B, Kocer B, Han S. A Rare and Serious Syndrome That Requires Attention in Emergency Service: Traumatic Asphyxia. Case Rep Emerg Med 2015;2015:359814.

29)Williams JS, Minken SL, Adams JT. Traumatic asphyxia--reappraised. Annals of surgery. 1968;167 (3):384.

30)Lee M-C, Wong S-S, Chu J-J, Chang J-P, Lin P-J, Shieh M-J, et al. Traumatic asphyxia. The Annals of thoracic surgery. 1991;51(1):86-8.

31)Bertelsen $S$, Howitz P. Injuries of the trachea and bronchi. Thorax. 1972;27(2):188-94.

32)Grillo H. Tracheal and bronchial trauma. Surgery of the Trachea and Bronchi Lewiston: BC Decker. 2004:271-90.

33)Sybrandy K, Cramer M, Burgersdijk C. Diagnosing cardiac contusion: old wisdom and new insights. Heart. 2003;89(5):485-9.

34)Spodick DH. Acute cardiac tamponade. N Engl J Med 2003. 684-90.

35)Peitzman AB. The trauma manual: Lippincott Williams \& Wilkins; 2002.

36)Thoracic trauma: Greaves I. Oxford University.Press; 2001.

37)Attar S, Hankins JR, Suter CM, Coughlin TR, Sequeira A, McLaughlin JS. Esophageal perforation: a therapeutic challenge. The Annals of thoracic surgery. 1990;50(1):45-9.

38)Eren MB, A. Toraks Travmaları. Ökten İG, A., editor: Sim Matbaacılık Ltd. Şti; 2003.

39)Halliwell B, Gutteridge JM, Cross CE. Free radicals, antioxidants, and human disease: where are we now? The Journal of laboratory and clinical medicine. 1992;119 (6):598-620.

40)Mattax LK DS, Kalaycı G, Giles Y, Özçelik C,
Sözüer E,, C. K. travma. Erkin C TK, Güloğlu R, Kurtoğlu M,, editors., editors: Medikal yayıncılık; 2005. 819-73.

41)Pepe PE, Potkin RT, Reus DH, Hudson LD, Carrico CJ. Clinical predictors of the adult respiratory distress syndrome. The American Journal of Surgery. 1982;144 (1):124-30.

42)Trupka A, Waydhas C, Hallfeldt $K$, Nast-Kolb D, Pfeifer K, Schweiberer L. Value of thoracic computed tomography in the first assessment of severely injured patients with blunt chest trauma: results of a prospective study. Journal of Trauma and Acute Care Surgery. 1997;43(3):405-12.

43)Voeller G, Reisser J, Fabian T, Kudsk K, Mangiante E. Blunt diaphragm injuries. A five-year experience. The American surgeon. 1990;56(1):28-31.

44)Oppenheimer L, Craven K, Forkert L, Wood L. Pathophysiology of pulmonary contusion in dogs. Journal of Applied Physiology. 1979;47(4):718-28.

45)Song JK, Beaty CD. Diagnosis of pulmonary contusions and a bronchial laceration after a fall. AJR American journal of roentgenology. 1996;167(6):1510-.

46)Shackford SR. Analytic Review: Blunt Chest Trauma: The Intensivist's Perspective. Journal of Intensive Care Medicine. 1986;1(3):125-36.

47)Velanovich V. Crystalloid versus colloid fluid resuscitation: a meta-analysis of mortality. Surgery. 1989;105(1):65-71.

48)Biddle TL, Paul NY. Effect of furosemide on hemodynamics and lung water in acute pulmonary edema secondary to myocardial infarction. The American journal of cardiology. 1979;43(1):86-90.

49)Miller HB, Taylor GA, McMurtry RY, McLellan BA. Management of blunttrauma. Baltimore:

Williams\&Wilkins; 1990. 191-92.

50)Ashbaugh DG. Bigelow DB. Petty TL. Levine BE. Acute respiratory distress in adults. Lancet. 1967;2:319323.

51)Ware LB, Matthay MA. The acute respiratory distress syndrome. New England Journal of Medicine. 2000;342 (18):1334-49. 
52)Zhang H, Slutsky A, Vincent J-L. Oxygen free radicals in ARDS, septic shock and organ dysfunction. Intensive care medicine. 2000;26(4):474-6.

53)Metnitz $P$, Bartens $C$, Fischer $M$, Fridrich $P$, Steltzer H, Druml W. Antioxidant status in patients with acute respiratory distress syndrome. Intensive care medicine. 1999;25(2):180-5.

54)Bernard GR, Artigas A, Brigham KL, Carlet J, Falke $\mathrm{K}$, Hudson L, et al. The American-European Consensus Conference on ARDS. Definitions, mechanisms, relevant outcomes, and clinical trial coordination. American journal of respiratory and critical care medicine. 1994;149(3):818-24. 